\title{
5
}

Legal Aid in Denmark

Bettina Lemann Kristiansen

\section{Introduction and Historical Background}

While equality before the law is a basic legal principle, it is often very costly to bring a case before the court and to employ lawyers. This means that many people, for all practical purposes, are deprived of legal aid if it is not free of charge, or almost free of charge.

If the need for legal aid is to be satisfied, this implies that citizens should know their legal position and their rights, or have a way of finding out about this, and that they should have the means to achieve these rights - if necessary through a court case. This entails finding out whether there is in fact a legal claim that can be tried by the courts, an administrative tribunal, or some other body. And finally, the claim must actually be made.

Enabling people to know their legal position is demanding for legislators as well as for the administrative authorities. Regulations have to be formulated in such a way that it is possible for citizens to know their legal

B. Lemann Kristiansen $(\bowtie)$

Law School, Jurisprudence, Aarhus University, Aarhus, Denmark

(C) The Author(s) 2018 
positions. ${ }^{1}$ It should at least be possible for the citizen to know where to go (which authority to go to) for further guidance. Furthermore, knowledge of the law is one thing; it is quite another thing to know one's legal position. This very often requires knowledge about administrative practice, which is not always available or accessible. This is often the case, for example, in regard to welfare regulation.

The ability to get your rights requires clarification of whether you actually have a case- a claim that can be brought before the court-and requires you to be able to bring the case to court. Although access to the court system is a core value in our society, actual access depends on various factors. A number of barriers face citizens bringing a case before the courtfinancial and others. Quite often citizens need help to get their rights.

In what follows, the term legal aid is used to refer to both pre-trial legal aid and legal aid in regard to lawsuits. The official scheme for legal aid distinguishes between these forms of legal aid, and the providers of the two types of legal aid are also different.

For centuries, there has been a strong tradition of legal aid in the Scandinavian countries, including Denmark. The point of origin was private and voluntary legal aid. Originally, legal aid was offered to people of limited financial means, that is, those who could not pay for the professional legal assistance they needed.

In Denmark, Danske Lov (Danish Act) (D.L. 1-9-12) stated in 1683 that lawyers, when ordered by the state authorities, were obliged to give legal aid to poor people such as widows, lunatics, and the defenceless, free of charge. This regulation was, of course, not very popular with the lawyers and thus this had little practical effect. This form of legal aid, stipulating free legal aid to poor people in regard to court cases, continued into the nineteenth century, but legal aid was restricted to legal aid for court cases.

In the eighteenth and nineteenth centuries the requirement for free legal aid to be given for lawsuits was expanded. Free legal aid depended on the citizen meeting certain financial conditions, and on the fact that it was deemed reasonable (by the authorities) to take the case to court (Betænkning 404/ 1966). Since 1827, the basic principles for granting free legal aid for lawsuits have been that the citizen had a good reason for taking the case to court, and that the citizen did not have the financial means to do so if public funding was not available. 
It was not until the general regulation on the Administration of Justice (Retsplejeloven), in 1916, that there was a law on free legal aid in regard to lawsuits. According to it, lawyers who had beneficium (who were on the list of court-assigned lawyers in criminal cases) were also obliged to give legal aid to people of limited financial means (Betænkning 404/ 1966, pp. 8-13).

The establishment and development of the constitutional state in the nineteenth century, with its core values and ideals of equality before the law, did not lead to changes in, or improvements of, the access to justice of ordinary people. A large part of the population still had no real access to justice. In the twentieth century, the legislative goal was real access to justice by means of public funding, subsidies or grants to ensure access to legal advice, and to cover legal fees and costs when bringing a case before the court.

In the 1960s, the regulations on free legal aid for lawsuits were adjusted. At the same time pre-trial legal aid was introduced. Citizens were given the right to free legal aid by lawyers if they met certain, mainly financial, criteria. However, awareness of this was not very widespread within the general population.

However, the need for legal aid is not limited to court cases. In Denmark, there is a strong tradition of legal aid in a broader sense.

In 1885, the first private legal aid office was established in Copenhagen by a group of students who were outraged by the lack of help for the poor (see also Chap. 12). This legal aid office is still active and is the largest in Denmark - it is now called the Copenhagen Legal Aid Office (Københavns retshjælp).

Since then, a number of similar private legal aid offices have been established. They are usually situated near universities or other institutions that provide the necessary volunteers-primarily law students or social work students.

In the 1970 s, various measures were taken to improve legal aid. Three of the most important of these were: first, as part of a very ambitious new law on social welfare (Bistandsloven 333/1974 section 28), local authorities now had a general obligation to provide citizens with free advice in order to help them overcome (social) obstacles. Although the focus was on weak or vulnerable families, this meant (at least in theory) free advice 
for all citizens, not just people in need of social welfare benefits; second, a special complaints tribunal was established to give citizens an easier and cheaper way of solving conflicts, by providing an alternative to court cases such as the Consumer Complaints Board (Forbrugerklagenævnet); and third, a lawyer-based free legal aid scheme was established in 1978. Lawyer-based legal aid offices (Advokatvagter) were established in a number of larger cities, where lawyers give free legal aid in the form of a short consultation and verbal advice.

Some of these measures are part of the welfare state. Legal aid is to some extent perceived as a public responsibility. The authorities are expected to help citizens gain knowledge of their legal position, are also expected to help citizens in regard to cases within the administrative system, so no further legal aid is needed. As we will see below, there is, in fact, a need for legal aid to supplement help from the authorities — in both areas.

Thus, lawyer-based legal aid offices and private legal aid offices are still at the core of the legal aid given outside of court cases.

As mentioned above legal aid has traditionally originated from the goodwill of lawyers and law students. And this is still the case, since legal aid to a great extent depends on voluntary action. In both lawyer-based legal aid offices (Advokatvagter) and private legal aid offices, lawyers and law students work without payment. To some extent the costs of office space and office supplies can be covered by a public grant. Most of lawyerbased legal aid offices are situated in law offices or, more commonly, work from public libraries or the like.

A brief introduction to legal aid research in Denmark is given below. After this, the public legal aid scheme in Denmark is described. The various providers of legal aid are presented and the use of the different forms of legal aid is described. Then, there is a description of the administration and costs of the legal aid system.

\section{Legal Aid Research}

In Denmark, there have only been a few studies on legal aid. Most of them focus on the need-and especially the unmet need-for legal aid. Others are focused on specific providers of legal aid and their users. 
In the 1970s, there was research on legal aid throughout the Nordic countries (Eskeland and Finne 1973; Eidesen et al. 1975; Sejr et al. 1977). In Denmark, this took the form of research into the need for legal aid. When researching the unmet need for legal aid, the starting point was to examine the existing legal aid possibilities. One of the most comprehensive studies was carried out between 1975 and 1977, in Aarhus (the second largest city in Denmark); on the hidden and unmet need for legal aid (Sejr et al. 1977). The study found a great need for legal aid and that it was for the most part unmet. Further details about this study are below.

The findings of this Danish study are very similar to those of studies on legal aid in other Nordic countries. Jon Johnsen (1987) carried out a historical, empirical, and legal political study of the field of legal aid, in which he also summarised existing legal aid studies. By putting together one Danish study and three Norwegian ones, he created a very comprehensive basis for his research. These studies concluded that there was an unmet need for legal aid: the research showed that $60 \%$ of the households included in the various studies had an unsatisfied need for legal aid. It was also found that people of the lower social classes were in greater need of legal aid than those better off.

These findings have been confirmed by later research (Norges offentlige utredninger (NOU) 2002, p. 18; Rui 2009; Broch Graver et al. 2001; Gadejuristen 2011). There is a need for legal aid in vital areas of life, and the studies show that people without means (financial and others) are in the greatest need. The need for legal aid is greatest in cases concerning various types of rights.

The most recent Danish study was carried out in 2009-i.e., 30 years after the first empirical research into legal aid in Gellerupparken. This study is based on a survey of a number of different legal aid offices-both lawyer-based and private (Lemann Kristiansen 2009a). The study examines who the clients are, what their need for legal aid is, i.e., what type of legal questions they have, and what help they are given. Comparison of this data with general statistics makes it possible to assess the unmet need for legal aid. This study is detailed below.

After a reform in 2007 relating to civil court cases, there was a drastic decrease in spending on legal aid. The government advisory board on 
legal matters carried out an inquiry into the consequences of the reform. A number of these were found to relate to the legal aid system. The Association of Lawyers hired a consultant bureau to examine this further. Surveys and interviews showed a clear shift away from legal aid by lawyers to aid provided in legal aid offices. Thus, this reform was very significant for legal aid in Denmark. More about the reform and its consequences follows.

Over the years, the Association of Lawyers has also carried out studies of various aspects of lawyers' legal aid work (Danske Advokater and Advokatsamfundet 2011; Advokatsamfundet 2011). Surveys show that only a few lawyers have legal aid as part of their daily work, and that many are very reluctant to take on legal aid cases, see below.

\section{Different Legal Aid Schemes ${ }^{2}$}

Someone who has legal questions or is in need of legal aid may be helped in various ways. Often, they may contact the administrative authorities and obtain information and, to some extent, advice. As regards court cases, the courts are obliged to provide guidance for citizens. Various types of private sector possibilities for legal aid are also available-first and foremost, lawyers and legal aid offices, but also private actors, such as trade unions and tenant associations.

The Administration of Justice Act (Retsplejeloven), section 323, stipulates that everybody has a right to basic verbal legal advice free of charge. Also, if certain financial criteria are met, there is a right to further legal aid. This form of legal aid is subsidised by the state.

The legislation provides for free legal aid for lawsuits if certain criteria are met: those set by the Danish Administration of Justice Act (Retsplejeloven, section 330 ff.). Free legal aid may be given by supplying a lawyer or by covering the costs of a trial by public funding or insurance.

Besides this distinction between pre-trial legal aid and legal aid in connection with legal proceedings or lawsuits there are also important distinctions between different providers of legal aid.

In the following, my starting point is the legislation on pre-trial legal aid. After this, the different providers of legal aid are examined and there 
is a description of the legislation on free legal aid, i.e., legal aid in connection with legal proceedings and court cases.

\section{Pre-trial Legal Aid}

Pre-trial legal aid is about giving citizens information about their legal position, and about how to get their rights (and help them do so if necessary). As mentioned above, the Administration of Justice Act (Retsplejeloven), section 323, stipulates that everybody has a right to basic verbal legal advice free of charge.

The public legal aid scheme is described in detail in administrative regulations which distinguish between different levels of legal aidreferred to as steps. ${ }^{3}$

Step 1 legal aid aims to clarify whether there is a legal problem or case. It is conceived of as a 'legal A\&E department', where you can find out whether you have a legal claim or not, and if so, what your possibilities are for pursuing your claim, and (if necessary) what the chances of financial aid are if you want to take it to court. The legal aid is limited to verbal advice. There used to be a list of subjects or types of cases that were excluded from legal aid (criminal cases, tax cases, and cases related to trade). Legal aid was also contingent on financial criteria. However, this basic form of legal aid now includes all citizens (regardless of income) and all legal questions (regardless of subject).

If further legal aid is needed, public funding depends on the citizen/ client meeting certain financial criteria. The financial limits are changed yearly by administrative order. The financial criteria are the same as those governing free legal aid in connection with lawsuits (see below). There are also certain non-financial criteria. The financial criteria are supplemented by a list of subjects or types of cases that are excluded from step 2 and 3 legal aid: criminal cases and cases related to trade or business are excluded.

Step 2 legal aid covers extended verbal legal advice, drawing up letters, summonses or subpoenas, the settlement of estates in divorces or simple wills or (pre)nuptial agreements. Step 3 legal aid covers disputes where a settlement or compromise is thought to be a possible outcome of the legal aid, so this type of legal aid is aimed mainly at preventing lawsuits. 
An important change was made in the administrative order regulating legal aid offices in 2014 (Bekendtgørelse 637/2014 om Retshjælp); this excluded cases involving administrative authorities from step 2 and step 3 legal aid. There is a general rule in Danish administrative law stipulating that administrative authorities are obliged to provide guidance within their area of responsibility (The Public Administration Act (Forvaltningsloven), section 7). If the citizen is dissatisfied with a decision of the administrative authorities, there are various ways to complain and have the case re-examined. In recent years, however, complaint tribunals have been abolished, and the possibilities for filing a complaint have been reduced. Legal aid can be provided to help file a complaint but, once a complaint has been filed, citizens are expected to manage without further legal aid. It is presumed that the guidance from the complaint tribunal is sufficient.

\section{Legal Aid Providers}

As regards pre-trial legal aid, the main providers are lawyers and legal aid offices. Most of the actors in the field of legal aid are private entities. Lawyers have traditionally been the linchpin of this system of legal aid. The general principle is that you must pay (yourself) for the lawyer's services, and the principal rule is that the citizens must pay for professional legal aid, for example, that provided by lawyers. Nevertheless, there are a number of public legal aid schemes that ensure that people without means are not prevented from getting the legal aid they need (see below).

As mentioned above, there is a strong tradition of legal aid in Denmark and of legal aid based on voluntary work. This has resulted in the establishing of various types of legal aid offices. The ones relevant to the legislation on legal aid are two types of legal aid offices: lawyer-based legal aid offices (Advokatvagter) and private legal aid offices (retshjælpskontorer). These both supplement the legal aid given by lawyers.

The private legal aid offices are the oldest ones. As mentioned previously, private legal aid offices were established by lawyers and law students who volunteered to give legal aid to people without means. The Copenhagen Legal Aid Office (Københavns Retshjælp) is the oldest one 
in Denmark. It was established in 1885 by law students who saw the need for legal aid, and that people without financial means often lacked the help they required. In 1936, a similar legal aid office was established in Aarhus (Århus Retshjælp). Since then, other legal aid offices have been established-typically near institutions of legal or social work education. The aim of these legal aid offices was to help people of limited means. However, later, these financial criteria were supplemented by criteria regarding subject-mostly in the form of a list of subjects or types of cases for which legal aid would not be given; this list has varied over time. It is not possible to say how many of these private legal aid offices there are, since they vary greatly in regard to background, structure, and the form of legal aid given. Those operating according to the legislation on legal aid can apply for public funding. There are about 30 of these.

Since the 1970s, there have been a number of legal aid offices staffed by lawyers, which provide free legal advice (Advokatvagt, which I here call lawyer-based legal aid offices). The lawyer-based legal aid offices were established on the lawyers' own initiative. By now, this type of legal aid office can be found in most of the larger cities in Denmark.

The establishment of these lawyer-based legal aid offices was made possible by a general improvement in the legal aid system which resulted from a reform in 1978. According to an EU (European Union) initiative, lawyers' services became subject to value added tax (Act 204/1978). The Danish Parliament then decided that this revenue should be devoted to increasing the subsidies on legal aid. The result was a relaxation of the financial criteria for granting free legal aid in regard to lawsuits, so more people were eligible for free legal aid. The subsidies for legal aid offices were also increased. As a result more legal aid offices-especially more lawyer-based offices-were established. They were seen as legal 'A\&E departments' giving free legal advice but they did (and do) not provide representation, or draft letters, et cetera. Only lawyers, and graduates who assist them, work in these legal aid offices. The work is voluntary and unpaid. Public subsidies cover some office supplies. Usually the lawyers' offices accommodate the legal aid offices, or the legal aid is offered at the local library.

As mentioned above, there is a distinction between various forms of legal aid. 
Step 1 legal aid, i.e., free verbal advice, is provided by lawyer-based legal aid offices and private legal aid offices. There is no public funding for lawyers giving this type of legal aid. If a lawyer provides this type of legal aid, it is either free of charge or the client has to pay for it-it is not subsidised. Some lawyers give this type of legal aid pro bono and thus free of charge for the client.

Step 2 and 3 legal aid is offered by private legal aid offices and by lawyers (but not lawyer-based legal aid offices). A public subsidy covers part of the bill from the lawyer, and the citizen/client pays the other part. Lawyers are paid 1030 DKK (Danish Krone)/137 € for level 2 legal aid. The client pays $25 \%$ of this. The lawyer is paid $2350 \mathrm{DKK} / 313 €$ for level 3 legal aid, of which the client pays half. Legal aid given by private legal aid offices, on the other hand, is free of charge.

To sum up, the citizen's right to legal aid under the legislation is quite substantial-in theory. However, as we will see, in practice there are limitations and obstacles. This leads to an unmet need for legal aid, as we also know from research regarding legal aid.

Both lawyer-based legal aid (lawyers and lawyer-based legal aid offices) and private legal aid offices are subsidised by the Government and are subject to different kinds of regulation regarding the criteria for legal aid, auditing (of accounts and of statistics), and annual accounts. See below.

Alongside these public legal aid schemes, there is an increasing number of different alternative legal aid initiatives. This includes a variety of institutions and organisations-mainly private entities and non-profit organisations. Often, they give legal advice in a specific field of law, for example, trade unions or tenant associations; others have a specific target group, such as artists or refugees. Some of these require subscription, membership, or payment of fees-others are free of charge. These alternative private legal aid initiatives seldom have public funding or subsidies. They are, therefore, not subject to the regulation of legal aid, including the financial and other criteria. A rather new form of legal aid is street level legal aid (Gadejuristen). This targets people such as the homeless or substance abusers. The idea here is to meet the clients where they exist-in the street (see Chap. 8).

A lot of legal aid offices are thus private entities or non-profit organisations with private funding and no public subsidies, meaning that there is 
no clear picture as to how many there are. The quality and extent of the legal aid supplied by them is also unknown.

To sum up, there are a great variety of legal aid providers in Denmark. With regard to legal aid covered by the legislation, and the administrative regulation of it, which lays down the criteria for legal aid - in so far as it is subsidised by public means - the primary providers are lawyers (law firms and lawyer-based legal aid offices) and private legal aid offices, which are subject to the regulation.

\section{The Use of Pre-trial Legal Aid}

Since the providers of pre-trial legal aid are many and very varied, and since not all apply for subsidies, there is no clear picture as to their use. However, focusing on the more official legal aid offices, namely the lawyer-based offices and the private offices, which work under the legislation and which have public funding (to some extent), it is possible to say something about how these are used.

Private legal aid offices have been studied by researchers. As mentioned above, one study was carried out in the 1970s. The basis of this study was the setting up of a legal aid office in a new residential area in Aarhus (Gellerupparken). Advertisements were placed in various locations in the area. The result was that a large number of people consulted the legal aid office-people who otherwise were not likely to seek professional legal aid. In the first two years (the period of the study) more than 1600 people contacted the legal aid office. In 55\% of the cases, advice was provided; in $45 \%$ of the cases more help was needed and obtained. In $63 \%$ of the cases that were concluded within the period of the study the client won the case in full, and a further $19 \%$ of the cases were won to some extent. Besides the legal aid office, a representative section of the population within the area was canvassed as to their legal problems. Two thirds of the population had legal problems and the average was 1.4 problems per household. These were legal problems for which they were not planning to seek help or advice. The legal aid office in Gellerupparken is still open.

What follows is based on my own research on legal aid in Denmark (Lemann Kristiansen 2009a). I carried out a survey in a number of 
selected legal aid offices; some lawyer-based and some private. The lawyers and legal advisers filled in a form for every new application seeking help over a period of 3-6 months. A total of 2398 responses were collected, and 262 cases (step 2 and 3 legal aid) were followed from beginning to end. In each of these cases a supplementary survey was made of the handling, the communication between the parties, and so forth. The results of the survey were compared with public general statistics. The primary purpose of the study was to examine existing legal aid offices: Who are the clients? What are the legal problems? What kind of help is needed and provided?

The study shows that $46 \%$ of the clients are men and $54 \%$ are women. The typical client is 40-49 years old; this group clearly over-represented, whereas the young and the old are under-represented. The typical client has a medium-length education and is a wage earner. Wage earners, even though they represent $48 \%$ of all clients, are still under-represented when compared with the general statistics for the areas in question. Pensioners and social welfare clients are slightly over-represented. The average income of legal aid clients is below that of the population in general.

The reason for contacting the legal aid office varies according to the type of legal aid office in question. In private legal aid offices questions regarding rental law are predominant (25\%); family law (18\%) and contract law (16\%) questions are also very common. In lawyer-based legal aid offices the clients mostly ask questions about tort law, tax law, criminal law, and debt problems. A lot of clients also ask about inheritance law and problems concerning the administration of estates.

Different groups of clients have different legal problems. Young people mainly have problems regarding rental law and contracts. Family law problems predominate among the 30-60-year-old clients. Older clients very often ask about inheritance law. So, legal problems change through life. Legal problems also vary depending on educational and occupational factors.

Most of the legal aid needed is legal advice (step 1 legal aid). In 83\% of cases, legal aid involves guidance or legal advice. $70 \%$ of the clients need information about their legal position, and $50 \%$ are expected to be able to cope on their own, once they have obtained advice (help to selfhelp). In this connection, the education level of the client is an important factor. The better-educated client is more often expected to be able to 
self-help. In $20 \%$ of the cases, further legal aid is needed (step 2 or 3 legal aid). Clients with a lower level of education, in particular, need this type of legal aid. In more than $50 \%$ of cases, Step 2 or 3 legal aid either leads to the client winning the case or to a settlement. This is a clear indication of the necessity for the legal aid, and that it is worthwhile for this type of help to be given. In the remainder of the cases, it has often proved impossible to proceed further, due to legal reasons or lack of evidence. One in eight cases is dropped by the client because of the time and inconvenience involved in proceeding with it. Only very rarely are economic reasons given for giving up a case.

To sum up, this study finds that there is a widespread need for legal aid, that legal aid clients come from a very broad section of the population, and that legal aid makes a difference. In short, it is well-established in research that a need for legal aid still exists.

It is also well-established that there is a great unmet need for legal aid. The unmet need can be seen in the growing number of people contacting legal aid offices. The annual reports of legal aid offices all show a substantial increase in the number of people demanding legal aid (Københavns Retshjælp2010,2011;Århus Retshjælp 2010,2011,2012; Gellerupparkens Retshjælp 2011; Silkeborg Retshjælp 2011). To give an example, the number of people who contacted Århus Retshjælp increased by 59\% in the period 2008-2011 (Århus retshjælp 2012). The two largest private legal aid offices in Denmark provided legal aid to 18,000 people in 2011. ${ }^{4}$

An unmet need is also demonstrated by the above mentioned study. It is a fair assumption that people living in cities other than Aarhus and Copenhagen have a similar need for legal aid and that there is therefore an unmet need for legal aid, since legal aid offices (both private and lawyer-based) are few and far between. The question remains how this need for legal aid is satisfied-or to what extent.

As we will see below, there has been a remarkable decrease in public expenditure on pre-trial legal aid provided by lawyers (step 2 and 3 legal aid). It is a fair assumption that there has been a similar decrease in its use but there are no data on this. Inquiries by the Association of Lawyers showed that only $18 \%$ of lawyers were involved in legal aid as part of their daily business (of which $12 \%$ were obliged to do so as part of being public defenders); $50 \%$ never gave legal advice under these regulations (Danske Advokater and Advokatsamfundet 2011; Advokatsamfundet 2011). 
Lawyers said that they did not find legal aid profitable. However, there are other factors at play. Law firms have changed in the way they are organised, and in the legal fields on which they focus. Law firms are larger than previously and have moved to the largest cities. This is partly due to a reform in the court system resulting in fewer courts, which are concentrated near the larger cities. Lawyers are primarily focused on and very specialised in fields of business law, and their clients are usually business corporations and firms. This results in a withdrawal from citizens' everyday law problems. And the possibilities for getting legal advice-let alone free legal aid-from lawyers are very limited.

There has also been a reduction in the number of lawyer-based legal aid offices. In 2004, there were approximately 100 such offices in Denmark. However, by 2011, the number had decreased to approximately 88 offices. This is due to a number of factors, including aforementioned general developments in the work of lawyers, and consequential difficulties in recruiting lawyers for legal aid offices. Lawyer-based legal aid offices experience great difficulties regarding the recruitment of volunteers (Advokatsamfundet 2011). There is no longer the same incentive. In the past, lawyers could keep up with different areas of law, and perhaps meet potential clients in the legal aid office, thus generating business for the firm. However, lawyers have now become more specialised, and do not have the same interest in keeping up with different areas of law; the typical clientele in law firms has also changed. Statistics from the lawyerbased legal aid offices showed that approximately 25,000 people per year used them in the period 1985-2001. However, since 2001, no statistics have been available (Betænkning 1436/ 2004).

In what follows, the legislation on free legal aid in connection to legal proceedings is described.

\section{Free Legal Aid (Fri Proces): Legal Aid in Regard to Lawsuits and Legal Proceedings}

The courts have a general obligation to provide advice on cases that might be brought before them. This mainly involves procedural advice in connection with filing a court case, taking out of a summons, and similar matters. 
In 2007, a reform was made concerning civil court cases. The purpose of this was to provide better access to justice. Its cornerstone was the introduction of small claims procedures. These give citizens a simple way to have their small claims (up to 50,000 DKK/6666 € and all cases with no financial issues) heard by the courts in summary proceedings without lawyers, in which citizens represent themselves.

The courts have an extended obligation to give guidance in certain types of cases, for example, in the administration of estates and execution of claims. However, the court has to tread cautiously when providing guidance and advice, because they must maintain impartiality. They, therefore, primarily give advice regarding procedural matters. This excludes all the more material questions, for example, what evidence and what arguments to present to the court. Advice regarding material questions can only be given when both parties are present (Betænkning 1436/ 2004, p. 321ff). This means that there is a general need for legal aid in the form of professional help with lawsuits and legal proceedings (Lemann Kristiansen 2009b).

If the case has to be taken to court various forms of legal aid can be provided. In some cases a lawyer can be assigned. The lawyer's fee is then paid by the state. In criminal cases, cases of coercive measures and certain cases regarding child custody the Court will appoint a lawyer.

Most Danish citizens (about 90\%) have insurance covering legal aid, i.e., primarily court fees and costs (Betænkning 1436/ 2004, p. 166f.; Betænkning 1113/ 1987, pp. 113-114; Betænkning 1341/ 1997, p. 644), although a study has shown that only $27 \%$ are aware of this (Retshjælpsordninger i Danmark 2002). The insurance does not cover the above mentioned pre-trial legal aid. Legal aid insurance is an obligatory and integrated element in various types of insurance, for example, car insurance or family/household insurance. However, there are a number of limits to this insurance. First, cover is usually limited (typically around $125,000 \mathrm{DKK} / 16,666 €$ ) and excess (typically around 2500 $\mathrm{DKK} / 333 €)$. Different types of insurance and different insurance companies have different rules on these financial limitations to legal aid. Second - and more importantly—-there is a list of subjects/types of cases not covered by the insurance. This list is the same for all insurance companies and means that, for example, family law cases and cases to do with 
employment are not covered. So, in reality, some of the most common and important cases seen from the citizen/client/policy holder perspective are not covered by the insurance. Cases brought before (administrative) complaint tribunals are not covered either. In small-claims court cases only the court fees and a very limited fee to the lawyers are covered. The initial court proceedings and the preparation of the case are also excluded. Third, a legal assessment of the case has to be made, usually by a lawyer, before the insurance company will agree to cover it.

If a person does not have legal aid insurance, or the insurance does not cover the case, he or she can apply for free legal aid for the lawsuit (fri proces), provided they meet the criteria for this. The legislation regarding free legal aid is found in the Administration of Justice Act (Retsplejeloven).

First you have to meet certain financial criteria set forth in the Administration of Justice Act (Retsplejeloven) section 325. The financial criteria are changed yearly by administrative order. According to the current financial criteria you can apply for free legal aid if your income is below $304,000 \mathrm{DKK} / 40,533 €(386,000 \mathrm{DKK} / 51,466 €$ for couples); you can add 53,000 DKK/7066 € for every dependent child under the age of 18 .

In connection with the preparatory work on reforms to civil court cases, it has been estimated how much of the population actually meet these financial criteria. In 1966, the figure was 85\% (Betænkning 404/ 1966 , p. 30). However, since then, the number has fallen dramatically. In the 1980 s, the estimate was $35 \%$ of the population (Betænkning 1436/ 2004 , p. 154). In 1988, the criteria were changed, so that $60 \%$ became eligible. Since then, the criteria have been adjusted every year. In 1995, however, it was estimated that barely $50 \%$ met the criteria (Betænkning1341/ 1997, p. 477). And most likely the figure has dropped further since then.

You must also have a good reason to file the lawsuit, which means that you have to have a fair chance of winning the case. However, in some types of cases (for example those involving housing or employment, or if you have won a case in a tribunal) this criterion is eased, so that you basically only have to meet the financial criteria. This is regulated in the Administration of Justice Act (Retsplejeloven), section 327.

These two basic criteria have been the same since the beginning of the nineteenth century but, of course, the contents of these criteria and their 
administration have changed many times. The aforementioned reform in civil court cases in 2007 brought about some important changes. The coordination and connection between legal aid insurance and free legal aid was strengthened, so that insurance is primary, and you can only get free legal aid if you do not have insurance, or if the insurance does not cover the case, or if the costs of the case exceed what is covered by the insurance. The administration of free legal aid was also changed. Since 2007, responsibility for administering the regulation on free legal aid is divided between the Ministry of Justice and the Courts. Appeals on free legal aid can be brought before a special administrative body (Procesbevillingsnævnet).

When there is a clear case for free legal aid, (the Administration of Justice Act, section 327) because a previous decision has been in favour of the citizen applying for free legal aid, e.g., either one by an administrative authority or by an approved private dispute tribunal, the Court can grant free legal aid if the financial criteria (The Administration of Justice Act, section 325) are met. In other cases, the Ministry of Justice decides if free legal aid is to be granted. The administration is placed in The Department of Civil Affairs (Civilstyrelsen), which is an agency under the Ministry of Justice. In these cases, the material criteria come into effect (Mavrogenis 2012). Among these are the importance of the case for the citizen; in tenancy cases, custody cases, employment cases, or cases concerning health issues, the criteria are eased. Other criteria are the chances of winning the case, the size of the claim (trifling cases are rejected, typically when the claim is below $3500 \mathrm{DKK} / 467 €$ ); whether the costs of the case are deemed unreasonably high, and whether it can be heard by an approved tribunal-if so, the citizen is advised to take the case to this tribunal (after which you can go to court if necessary). The aforementioned Consumer Complaints Board is one of these (18) approved tribunals.

If free legal aid is granted, the state will cover all costs incurred by the trial, regardless of whether you win or lose the case.

To sum up, the criteria for free legal aid being granted for lawsuits are quite strict in Denmark, compared with the neighbouring countries, but if free legal aid is granted, all costs are covered, which is a comparatively generous system. 


\section{The Use of Free Legal Aid in Lawsuits}

Since the 2007 reform, there has been a marked fall in the number of cases where free legal aid is granted. In the period from 2010 to 2015, the number of cases where the Courts granted free legal aid dropped by $60 \%{ }^{8}$ For free legal aid decisions from The Ministry of Justice/The Department for Civil Affairs there has been a decrease of $26 \%$ in the number of applications for free legal aid. Free legal aid is granted in approximately $30 \%$ of cases. ${ }^{?}$

The factors behind this decrease in free legal aid are manifold. Some of the main reasons include: First, the small claims proceedings that were introduced in the 2007 reform has led to more cases where citizens represent themselves, and many cases are settled before they come to court. Second, changes to do with authorities, for example, in regard to cases concerning the administration of estates, have resulted in decisions on free legal aid being moved from the Ministry of Justice to the courts. Third, the reform meant that, when people applied for legal aid although they had insurance cover for legal expenses, their application was rejected-it took some time for people to adjust to the new regulation. However, apart from all this, there has also been a remarkable decrease in civil court cases. Since the reform in 2007, civil lawsuits in City Courts have fallen markedly. In the period from 2008 to 2013, there was a $25 \%$ drop. ${ }^{10}$

To sum up, the use of free legal aid in court cases has decreased. However, as we will see, expenditure has not decreased.

\section{The Administration of, and Expenditure on, Legal Aid}

The Ministry of Justice is responsible for the administration of legal aid.

As mentioned above, free legal aid in regard to lawsuits is granted either by the Court or by The Department for Civil Affairs (by delegation from the Ministry of Justice).

In regard to pre-trial legal aid, the State Budget has an appropriation for legal aid. Or rather, there are two appropriations: one is for subsidies for legal aid by lawyers (offentlig retshjælp ved advokat), where the actual costs are covered, so it is demand-led. Legal aid is given to all those who 
apply and meet the criteria. The other appropriation is for legal aid offices (lawyer-based legal aid offices (advokatvagter) and private legal aid offices (retshjælpskontorerne)) - here the budget is fixed. This appropriation is distributed among the legal aid offices which apply and meet the criteria. There is also an appropriation for free legal aid (fri proces).

The tables below show expenditure on the different forms of legal aid in the period 2004-2011. This period is chosen to show the significance of the 2007 reform.

The first two figures show spending on pre-trial legal aid. Table 5.1 shows legal aid by lawyers and Table 5.2 shows legal aid by legal aid offices (both lawyer-based, and private legal aid offices).

As one can see, there is a quite substantial reduction in expenditure. As mentioned above, the factors behind this are manifold.

Since the civil court cases reform in 2007, there has been a marked reduction in spending on public subsidies for legal aid by lawyers (Offentlig retshjælp ved advokat), i.e., the subsidies covering part of the lawyer's fee. According to the administrative authorities' statistics, spending on this type of legal aid fell from 24.6 million DKK/ 346,666 € a year to 5.8 million $\mathrm{DKK} / 773,000 €$ a year in the first four years after the reform.

Lawyer-based legal aid offices (advokatvagter) and private legal aid offices (retshjælpskontorer) can apply for a grant once a year. In May each year, the available money is distributed among the legal aid offices that have applied and meet the criteria. This means that legal aid offices do

Table 5.1 Expenditure. Legal aid by lawyers

\begin{tabular}{lrrrrllll}
\hline Mill. DDK. & 2004 & 2005 & 2006 & 2007 & 2008 & 2009 & 2010 & 2011 \\
\hline Step 2 & $8 \cdot 9$ & $8 \cdot 6$ & $7 \cdot 8$ & $4 \cdot 2$ & $3 \cdot 4$ & $3 \cdot 0$ & $2 \cdot 4$ & $2 \cdot 6$ \\
Step 3 & $15 \cdot 6$ & $14 \cdot 7$ & $13 \cdot 7$ & $6 \cdot 4$ & $4 \cdot 7$ & $4 \cdot 3$ & $3 \cdot 7$ & $3 \cdot 2$ \\
Total & $24 \cdot 6$ & $23 \cdot 3$ & $21 \cdot 5$ & $10 \cdot 6$ & $8 \cdot 1$ & $7 \cdot 3$ & $6 \cdot 1$ & $5 \cdot 8$ \\
\hline
\end{tabular}

(Source: Domstolsstyrelsen)

Table 5.2 Expenditure. Legal aid offices

\begin{tabular}{lllllllll}
\hline Mill. DKK & 2004 & 2005 & 2006 & 2007 & 2008 & 2009 & 2010 & 2011 \\
\hline & 8.8 & 8.9 & 9.1 & 10.4 & 10.9 & 11.3 & 12.5 & 12.8 \\
\hline
\end{tabular}

(Source: The State Budget and Retsplejerådet) (Lawyer-based legal aid offices providing step 1 legal aid and private legal aid offices providing step 1, 2 and 3 legal aid) 
not know how much they will get until then. This makes for great uncertainty, and difficulties in regard to planning. About 90 legal aid offices apply yearly.

The subsidies depend on certain conditions. Legal aid offices have to satisfy requirements regarding their management, and the quality of legal aid and information given. They have to be open for a minimum number of hours.

As one can see, there has been an increase in the appropriation for this type of legal aid. However, the total sum still represents a considerable reduction. This led to criticism in the media. In 2012, a political agreement was reached that the annual appropriation should be increased by 7.5 million DKK/1 million $€$ for legal aid offices. This agreement was extended in 2014 (Aktstykke 58, of 2014). The appropriation for legal aid offices is now approximately 21 million DKK/2.8 million $€$ per year.

Thus, expenditure over recent years is (Table 5.3):

Expenditure on free legal aid for lawsuits is as follows (Table 5.4):

As can be seen, there has been an increase in expenditure. However, in the same period, the number of cases where at least one of the parties has been granted free legal aid is considerably smaller (Table 5.5):

Table 5.3 Expenditure. Legal aid offices

\begin{tabular}{llllll}
\hline Mill. DKK & 2012 & 2013 & 2014 & 2015 & 2016 \\
\hline & 18.6 & 20.7 & 21 & $21 \cdot 1$ & 21.9 \\
\hline
\end{tabular}

(Source: The State Budget)

Table 5.4 Expenditure. Free legal aid in regard to lawsuits

\begin{tabular}{lllllllll}
\hline Mill. DKK & 2004 & 2005 & 2006 & 2007 & 2008 & 2009 & 2010 & 2011 \\
\hline & 318.1 & 312.5 & 343.7 & 281.2 & 322.8 & 367.8 & 432.7 & 460.0 \\
\hline
\end{tabular}

(Source: Domstolsstyrelsen)

Table 5.5 Number of cases where free legal aid is granted

\begin{tabular}{lllllllll}
\hline Number of cases & 2004 & 2005 & 2006 & 2007 & 2008 & 2009 & 2010 & 2011 \\
\hline Ordinary cases & 2.941 & 2.888 & 2.674 & 1.703 & 1.059 & 927 & 915 & 803 \\
Rental cases & 1.235 & 1.128 & 1.081 & 560 & 254 & 214 & 176 & 161 \\
Family law/marital cases & 5.592 & 4.863 & 4.354 & 2.171 & 1.441 & 994 & 723 & 418 \\
Other cases & 224 & 253 & 249 & 177 & 689 & 2.840 & 2.477 & 1.535 \\
Total & 9.992 & 9.132 & 8.358 & 4.611 & 3.443 & 4.975 & 4.291 & 2.917 \\
\hline
\end{tabular}

(Source: Domstolsstyrelsen) 
So, although there has been a fall in the total number of civil court cases, and although there has been a reduction in the number of cases where free legal aid is granted, expenditure has still increased, showing that spending on individual cases must have increased.

As one can see, the reduction in case numbers since the reform is quite substantial. And this is true for all types of cases-except for 'other' cases: examples of these are small claims cases (where an increase was to be expected), cases where court decisions are executed, cases before the bailiff, and probate court cases. The reform also led to a shift towards bailiffs and probate courts. Since the reform, when there is no dispute, i.e., where the claim is not disputed and the problem involved is merely its execution, it can be brought before the bailiff without a prior court decision. This was originally limited to cases of up to 50,000 DKK/6666 € (i.e., the same as for small claims proceedings). In 2011 this was changed, so that cases of up to $100,000 \mathrm{DKK} / 13,333 €$ can be executed directly, if not disputed. This, of course, results in the shifting of a great number of cases from traditional civil court proceedings to execution. Free legal aid is much less frequently granted for these types of cases.

To sum up, total expenditure on pre-trial legal aid in particular has decreased substantially. There is no obvious cause for the decrease. The main factors, however, are, as mentioned above, the 2007 civil court cases reform and the introduction of small claims proceedings. Another factor is the fact that lawyers have reservations about legal aid. A third factor is the shift from legal aid by lawyers to legal aid offices (Retsplejerådet 2011).

\section{Concluding Remarks}

The Administration of Justice Act (Retsplejeloven), section 323, stipulates that everybody has a right to basic verbal legal advice free of charge and, if certain financial criteria are met, there is a right to further legal aid.

Research has shown a widespread need for legal aid, and that legal aid makes a difference. Research has established that this need continues to be unmet.

In general, it has become easier for Danish citizens to acquire information about their legal position, since this is very often accessible via the 
internet. However, not all citizens are able to find the correct information in this way. The administrative authorities are often very good at giving information via their homepages but, typically, they provide general information based on 'normal' or 'simple' cases. There is no indication as to what you can do if your case is atypical. So, citizens often find that their problems do not fit with the information available, which does not always match the complexity of the real problem. Very rarely does the information offered take into consideration the correlation between different areas of the law. Advice or guidance is often needed to make information usable, so that it can provide a basis for informed decision-making.

The supply of, and access to, pre-trial or pre-procedural free legal aid has changed over the years. Legal aid by lawyers subsidised by the Government is practically non-existent for the vast majority of citizens. A major factor is that the lawyers do not find legal aid profitable. However, other factors are also at play. The law firms have changed in the way they are organised and the legal fields that they focus on have also changed. Firms have relocated to the big cities, largely because of a reform in the court system that has led to fewer courts. Lawyers are primarily focused on and become specialised in fields of business law, and their clients are mainly business corporations and firms. This means they are no longer interested in citizens' everyday legal problems.

The lawyer-based legal aid offices have great difficulty in recruiting volunteers (Advokatsamfundet 2011). There is no longer the same incentive. There are fewer lawyer based legal aid offices, and the lawyers working there are often unfamiliar with the kind of legal questions they meet, since their primary work is related to business law.

Lawyers are still, however, an essential part of the Danish legal aid system, but there has been a clear shift away from legal aid provided by lawyers to legal aid offices (Retsplejerådet 2011 and Copenhagen Economics 2012).

The very few private legal aid offices providing general legal aid (as opposed to more specialised legal aid offices) are concentrated in the major cities, close to institutions of legal education where the necessary volunteers are found. Since these private legal aid offices only exist in a few places, access to this form of legal aid is very uneven and unequal. 
Some private legal aid offices provide legal advice over the telephone or by email, and, in this respect; you might say that their legal aid is nationwide. This type of legal aid is, however, usually limited to step 1 legal aid-verbal advice. The clients are, in fact, predominantly local (Lemann Kristiansen 2009a)..$^{5}$ Another problem or challenge is to ensure the quality of the legal aid. When law students or social work students are the main work force, close supervision by experienced lawyers is required. This is not always available free of charge, and the financial resources of these institutions are very limited.

Thus, part of the population is in reality cut-off from (free) legal aid. This is also true as regards the very basic form of legal aid. This has been a well-known fact for some time, and there has been some discussion of reforms to the civil procedure regulations (Betænkning 1436/ 2004, pp. 312-313, p. 334; Betænkning 1341/ 1997, pp. 437-439). The geographical differences are described as unfortunate but any more comprehensive reform of legal aid is deemed unrealistic_primarily for financial reasons.

The civil courts cases reform of 2007 has resulted in a change in the need for legal aid, and in a remarkable reduction in spending on it. The purpose of the reform was to give better access to justice; its cornerstone is the introduction of small claims proceedings, in which citizens represent themselves. However, this new form of court procedure has created new inequalities in access to justice. Not all citizens are able to determine on their own whether they in fact have 'a case', or to download the correct forms, fill them in, decide on what evidence to present before the court, and finally litigate the case. Thus a new need for legal aid has been created - but not met. Since the 2007 reform, there has been a marked fall in cases where free legal aid for lawsuits is granted.

In many ways citizens are expected to be self-reliant. This is also true in regard to cases involving administrative authorities. They are expected to find the relevant information, hand in the relevant applications, contribute the relevant facts and enter into negotiations or deliberations with the authorities. The gap between the resourceful and the disadvantaged citizen is growing.

This is also true in regard to legal aid. It is harder to find the legal aid you need if you are not a resourceful citizen, or if you do not live in one of 
the larger cities in Denmark. The need for legal aid is increasing and changing. Developments in the administrative system and the courts have not been reflected in the public legal aid schemes. There is a great need for further research and a coherent legal-political discussion in regard to legal aid (Johnsen 1978 and Vedsted-Hansen and Pedersen 1982). ${ }^{6}$ The legal aid scheme needs to be brought into line with the general developments in society, so that it provides nationwide and high-quality legal aid.

\section{Notes}

1. For these demands on the legislator see Evald (2009), pp. 33-52.

2. This section is based on Lemann Kristiansen (2009b) and (2013).

3 . It is optional for private legal aid offices whether they operate according to this distinction but it is a condition for getting public funding.

4. In comparison from statistics from the (100) lawyer-based legal aid offices showed that in 2001 they had approx. 25,000 clients. The lawyer-based legal aid offices no longer maintain statistics on their clients but, since then, the number of lawyer-based legal aid offices has decreased by $20 \%$, and, thus, I presume that the same is the case as regards the number of clients.

5. This survey showed that clients in the legal aid offices live very close by. A survey made in Århus Retshjælp (2012) focusing on the legal aid over the telephone showed the same pattern. Very few calls came from municipalities.

6. Here such a coherent legal political overhaul was demanded. Here it is pointed out that legal aid has been in a legal political vacuum for more than 70 years.

\section{References}

Advokatsamfundet. (2011). Rapport om advokatvagter i Danmark.

Århus Retshjælp. (2010). Århus Retshjalp Årberetning.

Århus Retshjælp. (2011). Århus Retshjalp Årsberetning.

Århus Retshjælp. (2012). Århus Retshjalp Årsberetning.

Betænkning 1113. (1987). Betankning om advokatretshjalp, fri proces og retshjalpsforsikring m.v. Afgivet af Justitsministeriets udvalg vedrørende Retshjælp m.v. 
Betænkning 1341. (1997). Småsagsudvalgets betenkning: småsagsproces, inkassoproces. Justitsministeriet.

Betænkning 1436. (2004). Reform af den civile retsplejelafgivet af Retsplejerådet. Vol. 3: Adgang til domstolene.

Betænkning 404. (1966). Betenkning om andring af reglerne om fri proces og organisationen af den vederlagsfri retshjalp. Afgivet af det af Justitsministeriet den 2. November 1960 nedsatte udvalg.

Bistandsloven (Law on Social Welfare) L333. (1974).

Broch Graver, A., (et al.). (2001). Rettshjelp. Oslo: Institutt for kriminologi og rettssosiologi, Avdeling for rettssosiologi, Universitetet i Oslo.

Copenhagen Economics, Danske Advokater \& Advokatsamfundet. (2012). Retshjalp i nød? En analyse af udviklingen siden 2007 og dens konsekvenser.

Danske Advokater og Advokatsamfundet. (2011). Advokaters syn på offentlig retshjalp ved advokat, fri proces og retshjalpsforsikring (SFI Survey).

Eidesen, A., Eskeland, S., \& Mathiesen, T. (Eds.). (1975). Rettshjelp og samfunnsstruktur. Oslo: Pax.

Eskeland, S., \& Finne, J. (1973). Rettshjelp. Oslo: Pax.

Evald, J. (2009). Lovsprogets tilgængelighed. In P. Andersen (Ed.), Om rettens tilgangelighed (pp. 33-52). Copenhagen: Jurist- og Økonomforbundets Forlag.

Gadejuristen. (2011). Dokumentationsprojektet—en undersogelse af udsattes retshjalpsbehov. Accessible via the homepage: www.gadejuristen.dk

Gallup. (2002). Retshjalpsordninger i Danmark. Rapport.

Gellerupparkens Retshjælp. (2011). Årsberetning.

Johnsen, J. T. (1978). Den norske rettshjelpsutredningen. En kritisk kommentar. Retferd, 8, 18-31.

Johnsen, J. T. (1987). Retten til juridisk bistand. En rettspolitisk studie. Oslo: Tano.

Københavns Retshjælp. (2010). Årberetning.

Københavns Retshjælp. (2011). Arsberetning.

Lemann Kristiansen, B. (2009a). Retshjalp i Danmark. Delrapport I: Beskrivelse af retshjalpstilbuddene, http://www.justitsministeriet.dk/forskning/rapportervedr-forskningspuljen/

Lemann Kristiansen, B. (2009b). Domstolenes tilgængelighed. In P. Andersen (Ed.), Om Rettens tilgangelighed (pp. 87-119). Copenhagen: Jurist- og Økonomforbundets Forlag.

Lemann Kristiansen, B. (2013). Retshjælp—fortsat et udækket behov? In T. Gammeltoft-Hansen, I. E. Koch, B. Lemann Kristiansen, \& S. Schaumburg-Müller (Eds.), Protecting the Rights of Others. Festskrift til Jens Vedsted-Hansen (pp. 83-101). Copenhagen: DJØF Publishing. 
Mavrogenis, A. (2012). Fri proces. Retshjalp. Copenhagen: Jurist- og Økonomforbundets Forlag.

Norges offentlige utredninger. (2002). NOU 2002:18 Rett til rett. Vurdering av konkurranseforholdene $i$ markedet for juridiske tjenester. Utredning fra Advokatkonkurranseutvalget, avgitt til Justis- og politidepartmentet.

Retsplejerådet. (2011). Retsplejerådets rapport, Redegørelse om retshjalp ved advokat m.v.

Rui, J. P. (Ed.). (2009). Rettshjelp fra kyst til vidde. Festskrift til Jusshjelpa i NordNorge 20 àr. Oslo: Gyldendal akademisk.

Sejr, L. et al. (1977). Retshjalp $i$ et lokalområde. Forskningsrapport, Aarhus: Aarhus Universitet.

Silkeborg Retshjælp. (2011). Årsberetning for Silkeborg Retshjalp.

Vedsted-Hansen, J., \& Pedersen, A. S. (1982). Hvor blev retshjælpspolitikken af?-Fra retspolitik til retsplejeteknokrati. Retferd, 22, 66-82.

Open Access This chapter is distributed under the terms of the Creative Commons Attribution 4.0 International License (http://creativecommons.org/ licenses/by/4.0/), which permits use, duplication, adaptation, distribution, and reproduction in any medium or format, as long as you give appropriate credit to the original author(s) and the source, a link is provided to the Creative Commons license, and any changes made are indicated.

The images or other third party material in this book are included in the work's Creative Commons license, unless indicated otherwise in the credit line; if such material is not included in the work's Creative Commons license and the respective action is not permitted by statutory regulation, users will need to obtain permission from the license holder to duplicate, adapt or reproduce the material. 